\title{
Implications of Restorative Justice on Children of Sexual Violence
}

\author{
Gayatri Dyah Suprobowati and Subekti
}

Faculty of Law, Sebelas Maret University, Indonesia

*Corresponding author. Email: gayatridyahsuprobowati@yahoo.com

\begin{abstract}
This study aims to explain the implications of restorative justice for children as perpetrators of sexual violence. So far, the imposition of punishments for the perpetrators of crimes is one proof of success in law enforcement efforts. However, because the perpetrator of sexual violence is carried out by a child, deciding on the punishment to be imposed is not an easy decision. Considering that a child has rights that must be properly guarded and protected. This research is a normative research using a statutory and conceptual approach. Data obtained by literature study on matters relating to the subject of study. The results show that the implications of restorative justice for children who are perpetrators of sexual violence can provide justice for children, victims, and their families. Settlement through restorative justice can be applied to child perpetrators who commit crimes of sexual violence because in Law Number 11 of 2012 concerning the Juvenile Justice System which has emphasized that the juvenile justice system is obliged to prioritize theapproach restorative justice and children as perpetrators of sexual violence. have the right to protection and fair punishment. Thus, it will prioritize restoration back to its original state and restore the pattern of good relations in the community so that children's rights are as stated in The 1945 Constitution of the Republic of Indonesia in article 28B section (2) and Law Number 23 of 2002 concerning Child Protection in conjunction with Law Number 35 of 2014 concerning Amendments to Law Number 23 of 2002 concerning Child Protection can be fulfilled.
\end{abstract}

Keywords: Restorative Justice, Child Perpetrators, Sexual Violence.

\section{INTRODUCTION}

Children are the next generation who continue the ideals of the nation, the definition of children based on article 1 section 1 of Law Number 23 of 2002 concerning Child Protection states that a child is someone who is considered not yet 18 years old, including children who are still in the womb.

Based on article 28B section (2) of the 1945 Constitution, it states that "every child has the right to survive, grow and develop, and has the right to protection from violence and discrimination. Children have a very unique character, this is because the things they do tend to be in accordance with their own feelings, thoughts, and desires. However, today many children are in conflict with the law due to their involvement in acts of sexual violence, both as perpetrators and victims who have violated the norms, laws and social norms that apply.
For example, three junior high and elementary school students in Tegal City, Central Java, committed same-sex sexual abuse of five of their peers who were still in elementary school. Children who become victims are aged 7-10 years. Before launching the action, the child who acts as the perpetrator persuades and threatens the victim, so that the victim is willing to do what the perpetrator asks. Generally, the factors that cause a child to commit acts of sexual violence are external influences. Benturan culture and customs are very difficult to avoid in this era of globalization, foreign cultures influence so that it appears a shift in culture and customs, in which it affects the mindset.

In addition, advances in the field of electronic technology that are increasingly rapidly also boomerang if they are not used properly. It is proven that the easy access of children to violent videos and sexual videos on 
television and applications from computers and mobile phones will certainly affect their mindset and mentality. Next, the family factor. Bad treatment in children can affect the mindset and character of a child, children can behave aggressively which often results in harm to those around them.

It also cannot be separated from social factors in the surrounding environment. Pergaulan are less well able to carry a child to act against the law. Feeling wanted to be seen and recognized in the group makes a child do everything he can to achieve his goals which leads to violence.

Law enforcement efforts often only focus on providing justice for victims, and unconsciously forgetting that the perpetrator is a child who still needs assistance and protection of his rights. A child as a perpetrator certainly gets pressure both socially and psychologically because he has been labeled as a perpetrator of sexual violence. Therefore, in order to provide protection for children, the issuance of of Law Number 11 of 2012 concerning the Juvenile Criminal Justice System, as a result of the ratification of the Standard Minimum Rules for the Administration of Juvenile Justice that it is important to have a new perspective in taking an action to resolve crime cases involving children by not taking formal channels and being diverted to settlements while still paying attention to justice for the perpetrators and victims because they are still a child who must be protected. In the Juvenile Justice System Law (UUSPA) article 1 section (6) and 5, it states that there is an obligation to carry out restorative justice orjustice restorative. Then with restorative justice, what are the implications for children as perpetrators of sexual violence, whether it is the right choice in guaranteeing the rights of children who still need protection.

\section{RESEARCH METHOD}

The type of research used is legal research with normative juridical methods which aims to find and describe the conceptual framework of positive law and Islamic law. This research is prescriptive by taking a statutory and conceptual approach. The data used is secondary data, with data collection techniques through literature study on matters relating to the subject of study.

\section{FINDINGS AND DISCUSSION}

Acts of sexual violence committed by children cannot be considered as a natural act, because these actions have violated the norms of decency and decency prevailing in society. On the other hand, children as perpetrators of sexual violence do not fully know for sure in determining whether their actions are right or wrong and estimating the risks or consequences. This can happen because children are still in the phase of developing and searching for their identity, so they are easy to be influenced by factors from and try new things.

There are factors that influence children in committing acts of violence, for example, external influences related to different cultures and customs, family and social factors in the environment, because of the weakness of parents in providing supervision, children will tend to imitate and practice what they do. seen by their peers. No exception because of the advancement of information and communication technology today.

The rapid advancement of information and communication technology brings positive and negative changes, especially for children. One of the negative impacts is that it is easier for underage children to access various pornographic sites. Because children and adolescents are not optimally able to take into account the consequences and control stimuli.

This is indicated by the number of children who are in conflict with the law through the number of cases of sexual violence committed by children as perpetrators which every year there are still perpetrators, from 20162020 there were 702 cases recorded which can be seen as follows:

Table 1. Details of Data on Cases of Children as Perpetrators of Sexual Violence Based on the Child Protection Commission (KPAI) 2016-2020.

\begin{tabular}{|c|c|c|c|c|c|c|}
\hline Year & $\mathbf{2 0 1 6}$ & $\mathbf{2 0 1 7}$ & $\mathbf{2 0 1 8}$ & $\mathbf{2 0 1 9}$ & $\mathbf{2 0 2 0}$ & Total \\
\hline $\begin{array}{c}\text { Children as } \\
\text { Perpetrators } \\
\text { of Sexual } \\
\text { Violence }\end{array}$ & 146 & 168 & 161 & 183 & 44 & 702 \\
\hline
\end{tabular}


The table above shows that the number of cases of children as perpetrators of sexual violence during the last five years has increased and decreased. However, in 2020 there was a very significant decline. However, in terms of sexual violence that categorizes children as perpetrators, it is necessary to have very good and strict supervision when children are active both at school, at home, or when children are traveling. In addition, with regard to children who are perpetrators of sexual violence, special treatment must be given so that they can realize the dangers without having to lose their rights.

Nowadays, the assumption that criminals must undergo the most severe relationships has become a doctrine among the people. Although, cases of sexual violence involving children as perpetrators must be punished and responsible for their actions because they have violated the applicable norms, laws and social norms, but the formal punishment process through imprisonment or imprisonment does not necessarily provide a deterrent effect and creates a bad view for the child. influential in his life.

Sexual violence is an act that violates the norms of decency and decency, it can also be interpreted as a heinous act related to lust, for example kissing, touching the genitals and breasts, including having intercourse before being legally married. Acts of sexual violence committed by children can start from the presence of elements of advances against the victim, this is a violation of the UUPA which is contained in origin $76 \mathrm{E}$ that "Everyone is prohibited from committing violence or threats of violence, coercion, deceit, committing a series of lies, or induce a child to commit or condone obscene acts".

Regarding children as perpetrators of sexual violence, the UUPA is used to impose criminal sanctions on children in conflict with the law (ABH). This is done so that the rights of children during the legal process can still be protected and fulfilled. The punishment for those who violate the UUPA article $76 \mathrm{E}$, contained in the UUPA article 82 as follows:

(1) Anyone who violates the provisions as referred to in Article 76E shall be punished with imprisonment for a minimum of 5 (five) years and a maximum of 15 (fifteen) years. years and a maximum fine of IDR 5,000,000,000 (five billion rupiah).
Table 2. Cases of Children as Perpetrators of Sexual Violence and their Legal Process

\begin{tabular}{|l|l|l|l|}
\hline Cases & $\begin{array}{c}\text { Age of } \\
\text { perpetrator }\end{array}$ & $\begin{array}{l}\text { Type of } \\
\text { violation }\end{array}$ & \multicolumn{1}{|c|}{ Legal process } \\
\hline A & 11 years & $\begin{array}{l}\text { Sexual } \\
\text { abuse of } \\
\text { more } \\
\text { than 1 } \\
\text { child The }\end{array}$ & $\begin{array}{l}\text { deliberation did } \\
\text { not reach } \\
\text { consensus, } \\
\text { proceeded to the } \\
\text { legal process, the } \\
\text { perpetrator's court } \\
\text { decision was } \\
\text { placed in LPKS } \\
\text { Pontianak }\end{array}$ \\
\hline B & 14 years & $\begin{array}{l}\text { Rape of a } \\
15 \text { year } \\
\text { old child } \\
\text { because } \\
\text { a friend } \\
\text { invited } \\
\text { him. }\end{array}$ & $\begin{array}{l}\text { Reported by the } \\
\text { victim's parents. } \\
\text { During the legal } \\
\text { process, he was } \\
\text { placed in an adult } \\
\text { detention center. }\end{array}$ \\
\hline C & 16 years old & $\begin{array}{l}\text { Pregnant } \\
\text { and } \\
\text { taking } \\
\text { away } \\
\text { underage } \\
\text { girlfrien } \\
\text { d }\end{array}$ & $\begin{array}{l}\text { Reported by the } \\
\text { victim's parents, } \\
\text { the perpetrator was } \\
\text { deposited in an } \\
\text { adult prison at the } \\
\text { request of the } \\
\text { parents to make it } \\
\text { easier for them to } \\
\text { visit. }\end{array}$ \\
\hline
\end{tabular}

(2) In the event that the criminal act as referred to in section (1) is committed by a Parent, Guardian, Child Caregiver, educator or educational staff, the penalty shall be increased by 1/3 (one third) of the criminal threat as referred to in section (1).

Therefore, children who become perpetrators of sexual violence can be held criminally responsible, if they have reached the age of 14 years. If the perpetrator commits a crime over the age of 12 years, but has not reached the age of 14 years, then the criminal threat imposed on the child as the perpetrator is a maximum of half of the adult sentence. However, if the punishment imposed on a child as a perpetrator is life or death, the maximum sentence given is 10 years in prison. The following is an example of cases of children as perpetrators of sexual violence and the legal process. 
However, efforts to implement the law's order to impose imprisonment on children are a last resort (ultimum remedium). Therefore, the best decision is in the form of an action to return the child accused to his parents so that he is educated and nurtured properly and correctly. The existence of restorative justice does not mean that all children's cases must be given a decision in the form of actions that are returned to their parents, because judges must of course pay attention to various elements, including:

1. Children for the first time commit acts of violence.

2. The child is sitting in school.

3. The crime committed is not a serious moral crime, a crime that results in loss of life, serious injury or lifelong disability, or a crime that interferes with or harms the public interest.

4. Parents or guardians of children can still take care and educate children properly and well.

The imposition of criminal sanctions for children in conflict with the law $(\mathrm{ABH})$ as perpetrators of sexual violence must consider their rights so as not to violate children's rights which have been specifically regulated by The 1945 Constitution of the Republic of Indonesia in article 28B section (2) that "Every child has the right to the continuity of life". live, grow and develop, and have the right to protection from violence and discrimination" and the articles of Law Number 23 of 2002 concerning Child Protection in conjunction with Law Number 35 of 2014 concerning Amendments to Law Number 23 of 2002 concerning Child Protection. In essence, every child has rights that are obligatory to be guarded, protected, respected by the state, and other people of whom are guaranteed protection both before the law and socially.

Efforts to protect the rights of children in conflict with the law are in line with article 2 letters a and b of Law Number 11 of 2012 concerning the Juvenile Criminal Justice System in providing fair punishment and ensuring protection of the behavior of children who commit acts of sexual violence by prioritizingapproach restorative justice through diversion efforts.

Diversion is an action or treatment to divert or place perpetrators of child crimes out of the criminal justice system, while the concept of restorative justice is the settlement of criminal acts involving victims, perpetrators, families of perpetrators and victims, and the community and parties involved in it.
Efforts to implement restorative justice through diversion in the handling of children's cases are contained in article 5 section (1) of Law Number 11 of 2012 concerning the Juvenile Criminal Justice System, namely that the juvenile criminal justice system must prioritize a restorative justice approach.

Legal action that is usually taken before implementing restorative justice is from law enforcement parties conducting investigations and investigations first, then trying to conduct deliberation for both parties. If deliberation cannot be reached, law enforcers in giving decisions makeefforts restorative justice by considering various aspects that must be met in accordance with the interests of children, victims, and their families.

Justice restorative justice is an alternative to the settlement of criminal assault which step of the criminal justice focused on the criminalization of which is converted into a process of dialogue and mediation involving victims, offenders, families, victim / perpetrator, and related parties to jointly realize an agreement on the settlement of criminal cases fair and balanced for both victims and perpetrators. This alternative puts forward the restoration to its original state and restores the pattern of good relations in the community.

Restorative justice as a judicial approach concept plays an important role in providing law enforcement for children in conflict with the law $(\mathrm{ABH})$ which focuses on justice and guarantees of protection that not only includes victims, but also perpetrators of sexual violence. Its implementation aims to:

a. achieve peace between victims and children;

b. Resolving child cases outside the judicial process;

c. Preventing children from deprivation of liberty;

d. Encouraging communities to participate; and

e. Instill a sense of responsibility in children.

Thus, the implementation of restoration justice is able to provide and protect children's rights which can be realized maximally in addition to acts of sexual violence committed by children. Therefore, alternative implementation of restorative justice will prioritize restoration back to its original state and restore the pattern of good relations in the community. 


\section{CONCLUSION}

The implications of restorative justice for children who are perpetrators of sexual violence are able to guarantee the protection of their rights as the next generation of the nation as well as the implementation of punishment can be carried out fairly. This happens, because the implementation of restorative justice not only provides justice for the victim but also the interests of the perpetrator, the family of the perpetrator/victim, and the parties involved correctly. Therefore, the rights of perpetrators of sexual violence can be considered so as not to violate the rights of children which have been specifically regulated by The 1945 Constitution of the Republic of Indonesia in article 28B section (2) of the 1945 Law and Articles of Law Number 23 of 2002 concerning Child Protection. in conjunction with Law Number 35 of 2014 concerning Amendments to Law Number 23 of 2002 concerning Child Protection.

\section{REFERENCES}

[1]. Adha, Muhammad Yogie. 2020. Penegakan Hukum Yang dilakukan anak di Wilayah Hukum Polresta Yogyakarta. Fakulats Hukum Universitas Islam Indonesia: Yogyakarta.

[2]. Annisa, Febriana. Penegakan hukum terhadap anak yang melakukan tindak pidana pencabulan dalam konsep restorative justice. Jurnal Hukum. Volume. 7 No. 2, diakses pada 2 Oktober 2021, pukul 21.02 WIB.

[3]. Fandinia, Yonna Diangrani, dkk. Implikasi Perumusan Prinsip Restorative Justice dalam Undang-Undang Nomor 11 Tahun 2012 Tentang Sistem Peradilan Pidana Anak Terkait Kasus Bullying di Kalangan Pelajar. hukum.studentjournal.ub.ac.id. Diakses pada 4 Oktober 2021 pukul 07.21 WIB.

[4]. Irmayani, Nyi R. 2019. Problematika Penanganan terhadap anak pelaku tindak kekerasa seksual selama menjalankan proses kasus hukum di Provinsi Kalimantan Barat. Pusat penelitian dan pengembangan Kesejahteraan sosial, Kementerian Sosial RI: Jakarta Timur.

[5]. Komisi Perlindungan Anak Indonesia (KPAI). 2020. Data Kasus Pengaduan Anak 2016 - 2020. bankdata.kpai.go.id. Diakses pada 3 Oktober 2021, pukul 08.04 WIB.
[6]. Konstitusi Republik Indonesia UUD 1945.

[7]. Marlina. 2010. Pengantar Konsep Diversi dan Restorative Justice Dalam Hukum Pidana. Medan: USU Press.

[8]. Mohara, Hanif Zehra. 2017. Penerapan saksi pidana anak sebagai pelaku kekerasan seksual yang dilakukan terhadap anak (studi putusan No. 1/Pid. Sus-Anak/2017/PN.TRG. Fakultas Hukum Universitas Sumatera Utara: Medan.

[9]. Mulyani, Sari Septi. 2019. Restorative Justice Bagi Pelaku Anak yang Melakukan Tindak Pidana Kekerasan Seksual terhadap Anak. Tesis, Program Magister Ilmu Hukum. Program Pascasarjana. Universitas Lambung Mangkurat.

[10]. Rokhamah, Ridho. 2013 Restorative bagi anak pelaku tindak pidana perkosaan anak perspektif hukum islam dan hukum positif. STAIN Ponorogo.

[11]. Suprobowati, Gayatri Dyah. 2019. Rekosntruksi Model Penyelesaian Kekerasan terhadap Perempuan Secara Adil Melalui Pengembangan Restorative Justice di Era Globalisasi. International Symposium on Research in Innovation and Sustainability 2019 (ISoRIS '19)28-29 August, Penang, Malaysia.

[12].Undang-undang nomor 11 tahun 2012 tentang Sistem Peradilan Pidana Anak.

[13].Undang-Undang Nomor 23 Tahun 2002 tentang Perlindungan Anak juncto Undang-Undang Nomor 35 Tahun 2014 tentang Perubahan atas UndangUndang Nomor 23 Tahun 2002 tentang Perlindungan Anak. 